\title{
ВИКОРИСТАННЯ ТЕОРІЙ РОЗВИТКУ ТА ПРОСТОРОВОЇ ОРГАНІЗАЦІЇ ЕКОНОМІКИ РЕГІОНІВ ДЛЯ ЇІ РЕФОРМУВАННЯ: ДОСВІД ЗАРУБІЖНИХ КРАЇН І КОЛИШНЬОГО СРСР
}

\author{
Черкаський державний технологічний університет, \\ Міністерство освіти і науки України, \\ кафедра фінансів, \\ бул. Шевченка, 460, м. Черкаси, \\ 18006, Україна, \\ тел: (0472)-71-10-57, \\ e-mail: finance@chdtu.edu.ua
}

\begin{abstract}
Анотація. Стаття спрямована на вивчення досвіду зарубіжних країн і колишнього СРСР в плані реформуванні економіки регіонів 3 використанням теорій їхнього розвитку та просторової організації. 3 цією метою відповідні теорії згруповані за їх приналежністю до основних шкіл економічної думки та практичною спрямованістю. Також розкрито досвід їх позитивного застосування. Так, теорії першої групи, що мають в основі класичну політичну економію, маржиналізм і неокласику та зорієнтовані на удосконалення просторової організації господарства (теорії розміщення виробництва і просторової організації економіки), найбільше застосування знайшли у Німеччині і колишньому СРСР. Теорії другої групи (плановоекономічного i кейнсіанського типу), що передбачають масштабну державну допомогу відсталим регіонам, як, наприклад, теорія державного регулювання розвитку регіонів, широко практикувались у СРСР і США. Теорії третьої групи (інституційного напряму), які націлені здебільшого на міжрегіональний перерозподіл економічного зростання (регіональної науки, “полюсів зростання", кластерів та ін.), використовувались у більшості країн світу, але особливо цінним для України $є$ досвід їх застосування у Франції, Італії та Фінляндії. Теорії четвертої групи (на базі неокласичного синтезу), що передбачають збалансоване використання ресурсного потенціалу регіонів (передусім теорія сталого саморозвитку регіонів), знайшли широке застосування в країнах $\mathrm{CC}$ і тому можуть стати особливо затребуваними в Україні у зв'язку з ії євроінтеграційними устремліннями. Саме остання група теорій має стати «ядром» в ансамблі теорій, на які доцільно спиратися в процесі реформування економіки регіонів України.
\end{abstract}

Ключові слова: економіка регіону, економічна теорія, економічні реформи, розвиток регіонів, просторова організація економіки, зарубіжний досвід.

\section{USE OF THEORY OF DEVELOPMENT AND SPACE REGIONAL ECONOMIC ORGANIZATIONS FOR ITS REFORM: EXPERIENCE OF FOREIGN COUNTRIES AND THE EXTERNAL USSR}

\author{
Cherkasy State Technological University, \\ Ministry of Education and Science of Ukraine, \\ Department of Finance, \\ Blvd. Shevchenko, 460, Cherkasy \\ 18006, Ukraine, \\ tel.: (0472) -71-10-57, \\ e-mail: finance@chdtu.edu.ua
}

\footnotetext{
Abstract. The article is aimed at studying the experience of foreign countries and the former USSR in terms of reforming the economy of the regions, using theories of their development and
} 
spatial organization. To this end, the corresponding theories are grouped according to their belonging to the main schools of economic thought and practical orientation. Also, the experience of their positive application is revealed. Thus, theories of the first group, which are based on classical political economy, marginalism and neoclassicalism, are oriented towards the improvement of the spatial organization of the economy (theories of production placement and the spatial organization of the economy), the greatest application was found in Germany and the former USSR. Theories of the second group (planned economic and Keynesian type), envisaging large-scale state aid to backward regions, such as the theory of state regulation of the development of regions, were widely practiced in the USSR and the United States. Theories of the third group (institutional direction), which are aimed primarily at interregional redistribution of economic growth (regional science, "growth poles", clusters, etc.), were used in most countries of the world, but their experience in France, Italy and Finland. Theories of the fourth group (based on the neoclassical synthesis), which envisage the balanced use of the resource potential of the regions (primarily the theory of sustainable selfdevelopment of the regions), have become widespread in the EU countries and may therefore become particularly popular in Ukraine in connection with its Euro-integration aspirations. It is the latter group of theories that should become the "core" of the ensemble of theories, which it is advisable to rely on in the process of reforming the economy of the regions of Ukraine.

Key words: economics of the region, economic theory, economic reforms, development of regions, spatial organization of economy, foreign experience.

Вступ. На важливості практичної зорієнтованості економічної науки й, зокрема, просторової економіки наголошував ще А. Льош: "Переді мною витає такий образ економічної науки, який подібно до архітектора, а не історика архітектури, не стільки описує, скільки творить" [1, с. 508].

Зрозуміло, що при реформуванні економіки регіонів важливо сповна використовувати “архітектурні” (конструктивні) можливості теорій їх розвитку i просторової організації, хоча вони й часто розроблялися тільки для пояснення певних явищ і особливостей.

Конструктивний потенціал теорій розвитку і просторової організації економіки регіонів відмічали Н. Бєлікова, В. Василенко, І. Возняк, Ю. Гаджієв, О. Гейман, О. Гранберг, Б. Данилишин, І. Дегтярьова, М. Джаман, В. Дорогов, Є. Качан, В. Король, Л. Лимонов, Є. Матвіїшин, В. Медвідь, О. Нєма, І. Підоричева, В. Реутов, С. Романюк, I. Сторонянська, М. Фащевський, Л. Чернюк та ін. Однак тільки у працях небагатьох авторів відмічається, яким саме чином і в яких країнах він використовувався.

Постановка завдання. При реформування економіки регіонів України цінним може бути досвід використання теорій їх розвитку i просторової організації в зарубіжних країнах і колишньому СРСР. Отже, він потребує узагальнення як в розрізі окремих теорій, так і загалом.

Результати. Основні теорії розвитку і просторової організації економіки регіонів за їх приналежністю до течій економічної думки і практичною спрямованістю логічно об'єднати в чотири групи:

перша - теорії, орієнтовані на класичну політичну економію, маржиналізм i неокласику та призначені насамперед для оптимізації просторової організації господарства (сільськогосподарського штандорту Й. фон Тюнена, промислового штандорту А. Вебера, просторової організації господарства А. Льоша та ін.);

друга - теорії планово-економічного та кейсіанського напрямів, які передбачають зміну спеціалізації регіонів, невідкладну державну допомогу кризовим регіонам тощо (спеціалізації регіонів, планування територіального розвитку, регіональної економіки планового типу, державного регулювання розвитку регіонів та ін.);

третя - теорії інституційного напряму, що орієнтовані на міжрегіональний перерозподіл економічного зростання (регіональної науки, кумулятивного зростання, 
“полюсів зростання”, “центр - периферія”, “дифузії нововведень”, інноваційного розвитку регіонів, кластерів, регіональної конкурентоспроможності та ін.);

четверта - теорії на основі неокласичного синтезу, що передбачають збалансоване використання ресурсного потенціалу регіонів за активної участі органів регіональної і місцевої влади (агломерації, нової економічної географії, людського розвитку, сталого розвитку, саморозвитку регіонів, нового регіоналізму та ін.).

Розглянемо як використовувалися в зарубіжних країнах і колишньому СРСР основні теорії розвитку і просторової організації економіки регіонів в аспекті їі реформування (удосконалення структури і територіальної організації, підвищення ефективності виробництва тощо). I почнемо з теорій першої групи.

Не виключено, що теорія сільськогосподарського штандорту Й. фон Тюнена, згідно з якою по мірі віддалення від міста, як центра споживання аграрної продукції, питомі витрати землі, праці й основних фондів швидко зростають внаслідок чого формуються концентричні кола (кільця) сільськогосподарської спеціалізації, слугувала самому автору для інтенсифікації й підвищення ефективності виробництва у його маєтку Телло (біля м. Росток у Німеччині).

В колишньому СРСР теорія Тюнена хоча й відносилася до розряду буржуазних, однак в неявному вигляді все ж використовувалася, зокрема при територіальній організації приміських аграрних та аграрно-промислових комплексів: ближче до міст вирощувалися більш інтенсивні сільськогосподарські культури, а з віддаленням від них - менш інтенсивні, з нижчою ефективністю виробництва. Це, до речі, підтвердило й спеціальне дослідження радгоспів Московської та Ленінградської областей. Воно показало, що приміські землі використовувалися більш інтенсивно, що дозволяло радгоспам підвищувати фондоозброєність. Завдяки цьому радгоспи залишались рентабельними навіть в умовах більш дорогої робочої сили [2].

О. Гранберг вважає, що модель “кілець Тюнена" в 1980-х рр. використовувалися на Кубі в якості схем розміщення нових плантацій на рівнині навколо населених пунктів - місць проживання аграріїв. При різних умовах конкретний склад поясів буде іншим, але принцип їх чергування зберігався [3, с. 43].

Уніфікована сільськогосподарська модель Тюнена (на базі моделей нової економічної географіï) дозволяє поширити іï використання на промисловий i транспортний сектори [4].

Теорія промислового штандорту А. Вебера дозволила з наукових позицій підійти не тільки до визначення оптимальних пунктів розміщення промислових підприємств із врахуванням факторів місцеположення (зокрема робочої орієнтації), фактора відстані до джерел сировини і споживачів продукції (транспортної орієнтації) та агломерації (ефекту від їх просторового зосередження), але й до обгрунтування промислового розвитку регіонів. Не випадково, ця теорія знайшла широке застосування, як у країнах 3 розвиненою ринковою економікою, так $\mathrm{i}$ в колишньому СРСР. Ïї практична спрямованість у країнах з ринковою економікою добре видна на прикладі бізнес-планів промислових підприємств, обов'язковим пунктом яких $є$ обгрунтування місця розташування промислового бізнесу, зокрема того, що започатковується. У колишньому СРСР теорію Вебера, хоча й високо оцінювали (М. Баранський, М. Морозов та ін.), однак безпосередньо (як буржуазну) не використовували. Водночас при розміщенні промислових підприємств усі “веберівські" та й інші фактори враховувалися, зокрема у формулі приведених витрат: Пв $=C+E K+T$, де $C$ - річні поточні витрати (на сировину, робочу силу тощо в місцях локалізації виробництва), $E$ постійна норма дисконту, $K$ - капітальні вкладення, $T$ - річні транспортні витрати. Ця формула використовувалася при розміщенні всіх великих промислових підприємств, хоча й одержані результати сильно коригувалася політичною необхідністю. Так, 
наприклад розрахункові приведені витрати для Волжського автозаводу в Тольятті були не мінімальними (мінімум припадав на Мінськ [5]), однак завод все ж побудували там, тому що необхідно було працевлаштувати працівників, які вивільнялися після завершення будівництва Волжської ГЕС.

На відміну від теорій розміщення виробництва, теорія просторової організащії господарства А. Льоша мало значно ширше поле для практичного застосування, оскільки в іiі рамках була зроблена спроба вирішення багатьох проблем розміщення не окремих підприємств, а підприємств усіх галузей, відштовхуючись від принципу загальної економічної рівноваги Вальраса [1]. На противагу А. Веберу, А. Льош більшого значення надавав ринкам збуту готової продукції (як головному чиннику розміщення підприємств), категорично стверджуючи, що правильним $\epsilon$ таке розміщення, яке забезпечує максимальні прибутки. Він же ввів і новий критерій оцінки розміщення підприємств різних галузей - інтереси всього господарства країни. Тому й нині багато теоретичних положень і пропозицій А. Льоша можна використати при виборі найбільш вигідних пунктів розміщення нових підприємств у заданому економічному районі, а формули, які він запропонував, - при аналізі окремих чинників розміщення, коло яких він значно розширив [6, с. 28].

Теорії другої групи вказують на велику роль у реформуванні економіки регіонів держави та іï окремих інституцій, тому й не дивно, що їх щонайбільше використовували в країнах $з$ централізованою, або дуже розбалансованою (кризовою) економікою.

Теорія економічного районування найбільше застосування знайшла у колишньому СРСР - через великі розміри його території i, зрозуміло, плановий характер економіки. Економічні райони, виділені ще в Плані ГОЕЛРО та в наступних схемах районування країни, використовувалися для розбивки народногосподарських планів по окремих територіях або розроблення планів розвитку самих районів. Оскільки ядро кожного економічного району складали чи в перспективі мали складати (у слабоосвоєних районах) один чи декілька територіально-виробничих комплексів (ТВК), то, звичайно, вагоме практичне значення мала відповідна теорія. Основи теорії ТВК заклав М. Колосовський. Цією теорією в колишньому СРСР керувалися і при реформуванні економіки староосвоєних районів (при модернізації її техніко-технологічної бази) і при освоєнні нових районів. 3 опорою на неї були створені потужні ТВК в Росії, Казахстані, Таджикистані.

Теорія спеціалізащії регіонів, що базується на загальноекономічних теоріях абсолютних переваг А. Сміта і порівняльних переваг Д. Рікардо, слугувала наріжним каменем структурної перебудови економіки майже усіх економічних районів i республік колишнього СРСР. Ця теорія є “правильною”, якщо спеціалізація районів не набуває гіпертрофованих форм. Прагнення ж колишнього СРСР зліквідувати залежність від імпорту бавовнику з Сгипту, Мексики, США та інших країн призвела саме до такої форми спеціалізації на його вирощуванні республік Середньої Азії, особливо Узбекистану, та, меншою мірою, Казахстану. В результаті основні запаси води найбільших рік регіону (Аму-Дар'ї і Сир-Дар’і) спрямовувались на бавовникові поля, які стали швидко засолювалися. При цьому плесо солоного Аральського моря відступило вглиб на 60 км, а саме море поділилося навпіл. Колекторно-дренажні води, що надходили 3 полів в русла річок, стали причиною відкладень 3 пестицидів, гербіцидів та солі на площі в 54 тис. км ${ }^{2}$ колишнього морського дна. Пилові бурі розносили сіль, пил і отрутохімікати на відстань до 500 км. Але найбільш складною екологічна ситуація й досі залишається на морському узбережжі [7]. Все це вказує на те, що теорією спеціалізації регіонів слід користуватися дуже виважено.

Теорія планування територіального розвитку, що поєднує теорії економічного 
районування, ТВК і спеціалізації регіонів, у колишньому СРСР була орієнтована на обгрунтування радикальних зрушень у розміщенні продуктивних сил, у структурі економіки регіонів на основі розроблення і реалізації регіональних програм і великих інвестиційних проектів. “Золотий вік” цієї теорії припадає на 1957-1965 рр., коли система управління і планування економіки СРСР базувалася на територіальному принципі.

Теорія регіональної економіки (планового типу), яку в колишньому СРСР започаткував М. Нєкрасов, була синтетичною і не мала самостійної сфери практичного застосування. Водночас вона мала на меті зблизити теорії розвитку і просторової організації регіонів планового і ринкового типів, аби з більшою повнотою використати конструктивний потенціал і одних, і других.

Зрозуміло, що теорії розвитку економіки регіонів планового спрямування, які мали широке застосування в СРСР, в т. ч. і для обгрунтування заходів 3 iii реформування, не могли мали безпосереднього застосування в країнах ринкового типу, хоча окремі їх положення і знайшли відгук у відповідних теоріях кейнсіанського напряму, в т. ч. і щодо їх практичної орієнтації.

Загострення проблем розвитку регіонів, поглиблення асиметрії в рівнях їхнього розвитку навіть самих ліберальних економіках вимагає відповідних дій 3 боку державних органів. Тому теорія державного регулювання розвитку регіонів донині залишається досить затребуваною. Вона передусім передбачає державну підтримку проблемних регіонів, Ця підтримка особливо необхідною була у 30-х рр. ХХ ст., коли провідні країни світу попали у “лещата” жорсткої кризи. Для подолання диспропорцій в рівнях розвитку регіонів, розвантаження столичних і великих міст А. Льош пропонував стимулювати розвиток відсталих регіонів на основі розміщення в них нових підприємств на пільгових умовах [1]. Більш радикальним був Е. Деннісон, який зауважував, що ключовим у економічному зростанні відсталих регіонів $\epsilon$ людський фактор, який потребує підвищення рівня зайнятості населення, рівня його освіченості i професійності [8].

У США підтримка депресивних регіонів здійснювалася з використанням таких інструментів, як позики приватним підприємцям і місцевим органам влади, проведення громадських робіт тощо. У Франції для підприємств, які розміщувались не в столичному регіоні, передбачалися субсидії та податкові пільги. У Російській Федерації для стимулювання розвитку регіонів зі складним кліматичними умовами введено регіональні коефіцієнти надбавок до заробітної плати. Досвід цих країн може бути корисним для України в плані випереджуючого розвитку проблемних регіонів (старопромислових, сільських, гірських, екологічного лиха та ін.).

Подальший розвиток регіонів, особливо проблемних, економіка яких щонайбільше потребує заходів із реформування економіки, в умовах ринкової економіки здійснюється шляхом розробки регіональних програм (комплексних i галузевих) згідно теорії планування регіонального розвитку. Перша така програма була розроблена і реалізована на практиці у США, де 1933 р. президент країни Ф. Рузвельт підписав акт TVA (Tennessee Valley Authority Act of 1933) про заснування повністю державної корпорації з управління майном (body corporation), яка одночасно була i державною корпорацією 3 територіального розвитку. Програма територіального розвитку економіки долини річки Теннессі передбачала її модернізацію за допомогою цілого ряду великих інфраструктурних проектів: створення електростанцій, будівництва доріг і каналів. На перших етапах реалізації програми роботу було надано 40 тис. громадян. Для захисту довкілля проводилися лісонасадження, велася боротьба 3 ерозією грунтів, контролювалася викиди промисловості. Пік фінансування програми 
припав на 1950-1955 роки. Цікаво, що TVA, як держкорпорація, функціонує й донині [9].

У післявоєнний період теорія планування регіонального розвитку, збагачена неокейнсіанськими i, почасти, інституціональними ідеями, отримала "друге дихання". У Франції з 1960-х рр. вона дала поштовх розвитку регіонів, що були утворені після проведення адміністративно-територіальної реформи. А для стимулювання розвитку проблемних регіонів було створено Агентство з питань координації та планування регіонального розвитку (DATAR). Воно відповідало за реалізацію регіональних аспектів розвитку національної економіки. Крім того, це агентство розподіляло кошти спеціального фонду регіонального розвитку (FIAT) - на реалізацію проектів розвитку інфраструктури. У Японії також широко поширена практика розробки планів розвитку окремих територій. Одним із таких планів став план реконструкції Японських островів (крім чотирьох основаних). У Росії традиційно розробляються програми розвитку як регіонів мезорівня (окремих областей і республік), так і макрорівня (“Сибір”, “Далекий Схід”).

Теорії третьої групи вирізняються тим, що вони поєднують положення не тільки економічної, а й ряду суміжних наук (що загалом характерно для інституціоналізму).

Так, засновник регіональної науки (комплексної міждисциплінарної науки) У. Ізард (Айзард) досліджував розвиток регіонів з економічних, соціальних, політичних, історичних, екологічних та інших позицій. Разом з В. Леонтьєвим, Р. Страутом та іншими ученими розробив моделі (в т. ч. гравітаційні) оптимального розміщення виробництва та формування промислових комплексів, які були покладені в основу створення регіональних програм економічного розвитку в США, Великій Британії та інших країнах. Значна частина цих програм була успішно виконана. На їх розробку були зорієнтовані й регіональні економетричні моделі: КК (Кейнса - Клейна), РВ (Філіпса - Бергстрома), WJ (Вальраса - Йохансена), WL (Вальраса - Леонтьєва), MS (Муса - Сарджента) та ін. Отже, заслугою У. Айзарда та його послідовників є те, що вони досягнення теорії регіональної науки втілили у конкретні програми і проекти регіонального розвитку.

Широкі можливості щодо практичного застосування має базова модель кумулятивної теорії Г. Мюрдаля. Вона зазвичай використовується в тих країнах, які бачать необхідність у збільшенні конкурентних переваг певних регіонів (за рахунок їх спеціалізації, ефекту масштабу тощо). Так, в Ірландії конкурентоспроможність графства Клер була значно підвищена у зв'язку з будівництвом у м. Шеннон міжнародного аеропорту та створення вільної промислової зони, в якій були розміщені потужні виробництва високотехнологічних компаній.

Теорія “полюсів зростання" Ф. Перру та його послідовників застосовувалася передусім для активізації розвитку регіонів, особливо депресивних, шляхом розміщення в них підприємства лідируючих галузей, які стають полюсами тяжіння факторів виробництва, оскільки забезпечують найбільш ефективне їх використання. Вона виявилася особливо затребуваною в об'єднаній Європі (найбільше у Франції, Іспанії та Італії), Туреччині, Австралії, Бразилії, Колумбії, Китаї, нових індустріальних країнах та ін. У більшості країн вона принесла позитивні результати, особливо в плані розвитку проблемних регіонів. В Іспанії, наприклад, колись відстала Каталонія завдяки розвитку (в “полюсній” формі) мікроелектроніки та телекомунікацій стала одним із світових лідерів в цих галузях і одним з найбільш розвинених регіонів країни [10].

Водночас деякі автори відмічають, що штучне насадження «полюсів зростання», коли вони не вписуються за багатьма характеристиками (залучення робочої сили, забруднення довкілля та ін.) у зовнішнє середовище регіонів, то це не приносить очікуваних результатів. В цьому випадку вони виглядають як «замки в пустелі». 
Такими, на думку С. Конті, є “полюси зростання" на базі нафтохімічних підприємств в регіоні Меццоджорно, що в Південній Італії [11, с. 257-259].

Але разом з тим, в умовах депресивного стану багатьох українських регіонів досвід використання теорії “полюсів зростання” може бути корисним для розробки стратегіï реструктуризації та інноваційного оновлення промислових центрів, збільшення кількості динамічно зростаючих міських поселень і, відповідно, регіонів.

3 теорією "полюсів зростання" кореспондує теорія "иентр - периферія" Дж. Фрідмана. Вона слугує для обгрунтування концентрації ефективної господарської діяльності у відносно невеликих ареалах, звідки імпульси розвитку (інновації тощо) поширюються на периферійні регіони. Оскільки важливою складовою цієї теорії $\epsilon$ процес просторового поширення інновацій, то це поєднує іiі з теорією “дифузіі нововведень” Т. Хегерстранда. Обидві ці теорії знаходять широке застосування в країнах, де очевидні “провали” в рівнях розвитку окремих їх частин і регіонів, наприклад Півночі і Півдня Італії, і які ставлять за мету реформування їх економіки на інноваційних засадах.

Звичайно, цим цілям щонайбільше відповідають теорії інноваційного розвитку регіонів (регіональних інноваційних систем, інноваційного регіонального зростання, інноваційних мереж, "регіонів, що навчаються" та ін.). Теорії такого спрямування почали з'явилися всередині 80-х рр. ХХ ст., вони стали відповіддю на перехід від індустріального до інформаційного суспільства. Їх використання сприяло формуванню технопарків і технополісів (у США, Японії та інших країнах), активізації інноваційної діяльності у відсталих регіонів та розвитку в них інноваційних галузей. У Великобританії (в контексті теорії інноваційного регіонального зростання), компаніям, що розвивають інформаційний сектор у депресивних регіонах, надаються значні державні субсидії [12].

На сьогодні однією 3 найбільш затребуваних в практичному сенсі, в т. ч. i контексті реформування економіки регіонів, є теорія кластерів М. Портера. Вона розглядається багатьма науковцями як наукова платформа, що забезпечує найбільш гнучкі форми кооперації, координації та інтеграції спільних зусиль економічних суб'єктів [13, с. 281-284].

У світі є досить багато прикладів створення високоефективних кластерів. Значний досвід їх створення нагромаджено у індустріально розвинених країнах. Наприклад, у США функціонують 380 кластерів. У них зайнято більше половини робочої сили США і виробляється $60 \%$ обсягу промислової продукції країни. Деякі кластери є дуже великими. Так, до Каліфорнійського виноробного кластера входять 680 комерційних винарень, що мають прямі зв'язки з тисячами виноградарів. Чимало кластерів США мають чітко виражену фармацевтичну спеціалізацію. Більшість 3 них фінансується венчурним капіталом.

Особливо важливим для України, що прагне сьогодні до євроінтеграції, є досвід країн $\mathrm{CC}$, зокрема Італії та Фінляндії. Пояснити це можна тим, що в нашій державі необхідно розрізнені, малопотужні (“парцелярні”) виробництва об'єднати у «пучки» (кластери) i, крім того, диверсифікувати структуру конкурентоспроможного сектору національної економіки, зокрема на регіональному рівні.

Кластери, що виникають на основі малих та середніх підприємств в Італії, називаються “індустріальними округами”. На них припадає $30 \%$ усіх зайнятих. Найвідомішим у світі $є$ індустріальний округ з виготовлення взуття, до якого входять компанії Ферагамо й Гучі та їх субконтрактні постачальники (технологічного обладнання та оснастки, шкіряних матеріалів, деталей взуття тощо). Члени індустріального округу отримують прибутки від спільної виробничо-інноваційної діяльності та маркетингових заходів. 
Досвід створення кластерів у Фінляндії став зразковим прикладом диверсифікації економіки: від дерево-та металообробної промисловості - до високотехнологічних галузей. Всього було визначено 13 напрямів формування та розвитку кластерів: високотехнологічний бізнес, нанотехнології, харчова промисловість, енергозберігаючі технології, біотехнології, здоров'я та медицина, деревообробна промисловість та ін. Було також сформовано чотири високотехнологічні регіони, які об'єднують 23 регіональні кластери. Зокрема, до регіону Оулу входить інформаційно-комунікаційний кластер високого рівня, ядром якого є компанія Nokia.

Зарубіжна практика кластеризації економіки регіонів підтверджує доцільність та актуальність створення кластерних структур в Україні, що сприятиме підвищенню конкурентоспроможності як окремих підприємств, зокрема малих і середніх, так i регіонів та загалом країни. Це, зокрема, вказує на те, що теорія кластерів змикається 3 теорією регіональної конкурентоспроможності, яка активно розвивається як за кордоном (М. Портер, І. Бегг, Р. Камані, Дж. МакКомбі, Р. Мартін, М. Сеттерфільд, Л. Шеховцева та ін.), так і в Україні (В. Василенко, Л. Ковальська, Ю. Орловська, Л. Чернюк та ін.). В умовах глобальної конкуренції ця теорія може використовуватися в усіх країнах, особливо тих, які сильно інтегровані у світогосподарські зв'язки і гостро потребують підвищення конкурентного статусу регіонів в геоекономічному просторі.

Теорії четвертої групи (на базі неокласичного синтезу) поєднують поряд з новими положеннями ключові ідеї більш ранніх теорій. Так, сучасна теорія агломерації, яку найбільш точно описує модель П. Кругмана і П. Ромера, враховує положення теорії А. Вебера, але пояснює причини їх виникнення та основні характеристики впливом випадкових факторів та зростаючою віддачею від масштабу. Конструктивні положення цієї теорії знайшли застосування у Великій Британії, Південній Кореї та ряді інших країн, зокрема при стимулюванні розвитку та регулюванні (в т. ч. й розвантаженні) промислових та міських агломерацій. Особливих успішним застосування цієї теорії виявилося у Південній Кореї. У ній вдалося добитися перенесення частини промислових підприємств із найбільших мегаполісів (Сеул, Пусан, Тегу та ін.) у містасупутники та сільські райони [14, с. 270].

Теорія нової економічної географії П. Кругмана, яка сформувалася порівняно недавно, цілком закономірно, поки не отримала широкого практичного застосування. Однак на можливостях іï застосування, зокрема в практиці освоєння економічного простору Західної Арктики, наголошують російські науковці [15, с. 190-191]. На їх думку, значущою є виявлена П. Кругманом закономірність виникнення регіональної агломерації. Економічний зміст цієї закономірності полягає в тому, що при утворенні агломерації (як основи економічного освоєння регіонального простору) більше значення має доступ до ринку (розвиненість регіональної системи комунікацій), ніж ефект від масштабу виробництва, транспортних витрат чи мобільності факторів виробництва. Водночас через розвиненість комунікацій (як, наприклад, у Бельгії та Нідерландах) бізнес розвинених країн отримав можливість переносити виробництва у менш розвинені, де, зокрема, дешевша робоча сила. Але можливий і зворотній ефект, коли розширення масштабів господарської діяльності, приміром освоєння родовищ Західної Арктики, може стати імпульсом для розвитку регіональної системи комунікацій i, отже, регіонів.

Теорія людського розвитку (в їі регіональній версіі) є однією із засадничих для Міжнародної організації праці, зокрема при розробці рекомендацій для країн, що входять до неї (а це 185 країн світу, в т. ч. й Україна), щодо заходів з регіональної соціальної політики. Ця теорія орієнтує на підвищення добробуту людей, розвиток соціальної інфраструктури, зняття соціально-політичної напруги, соціальний прогрес, у т. ч. й на регіональному рівні. 
Країни, що підписали у 1992 р. базові документи Конференції ООН зі сталого розвитку в Ріо-де-Жанейро та підтвердили їх через 20 років на конференції "Рio+20" (а це близько 130 країн), зобов'язалися сприяти збалансованому розвитку економічної, соціальної та екологічної складових на різних рівнях - від глобального до локального. В основі їхньої діяльності лежить теорія сталого розвитку, базові засади якої сформульовані Комісією Г. Г. Брундтланд та Г. Дейлі.

Теорія саморозвитку регіонів П. Ромера (на основі їх ресурсного потенціалу) практикується в багатьох країнах. Найбільш успішно вона застосовується в тих із них (Франція, Польща та ін.), де під неї спеціально проведена реформа $з$ децентралізації управління, зокрема адміністративна. Таким чином створюються передумови для формування фінансово спроможних територіальних одиниць. Так, у Франції у 80-90х pp. $\mathrm{XX}$ ст. в результаті децентралізації регіони стали повноправними адміністративними одиницями, які укладали контракти типу “держава - регіон”. Але навіть за цими контрактами держава надає підтримку тим проектам, які передбачають зростання зайнятості, розвиток освіти, охорони здоров'я тощо. Це вказує на те, що теорія саморозвитку регіонів на практиці узгоджується 3 теорією державного регулювання розвитку регіонів.

У Польщі в 1990 р. задля організаційної підтримки саморозвитку регіонів була впроваджена трирівнева система адміністративно-територіального поділу (гміни, повіти, воєводства) й, відповідно, проведена децентралізація управління. Таким чином було створено засади для розвитку регіонів на принципах фінансової самодостатності, що цілком відповідає сучасним теоріям і моделям управління регіональним розвитком в $\mathrm{CC}$.

Теорія нового регіоналізму М. Кітінга передбачає поєднання політики саморозвитку регіонів з політикою підтримки слаборозвинених регіонів. Вона особливо широко застосовується в ЄС, зокрема в рамках моделі “Європа регіонів”. Ще більше вона актуалізувалася після приєднання до ЄС десяти країн Центрально-Східної Європи. Ця теорія орієнтує владні структури на подолання різко асиметричного розвитку регіонів, підвищення їх конкурентоспроможності, розвиток транскордонного співробітництва тощо. А так звана ініціатива INTERREG передбачає не тільки економічну співпрацю регіонів сусідніх країн, але і взаємодію їх органів влади.

На думку Ю. Підоричевої, для ефективного реформування економіки регіонів необхідним є використання не якоїсь однієї теорії, а раціональне поєднання різних теорій, зокрема з інноваційною компонентою [16, с. 94]. На нашу думку, для цих цілей слід сформувати органічний ансамбль 3 теорій просторової організації господарства, державного регулювання розвитку економіки регіонів, “полюсів зростання", інноваційного розвитку регіонів, кластерів та сталого саморозвитку регіонів.

Висновки. Для успішного реформування економіки регіонів в Україні слід спиратися на відповідні теорії іiі розвитку і просторової організації та досвід їх застосування у зарубіжних країнах і колишньому СРСР. На сьогодні цих теорій $\epsilon$ досить багато, тому їх логічно об'єднати в групи за приналежність до основних шкіл економічної думки та практичною спрямованістю. Відповідно можна виділити теорії, що мають в основі: класичну політичну економію, маржиналізм і неокласику (теорії розміщення виробництва і просторової організації економіки); планово-економічного та кейсіанського напрямів (державного регулювання розвитку регіонів та ін.); інституційного напряму (регіональної науки, “полюсів зростання", кластерів та ін.); неокласичного синтезу (сталого саморозвитку регіонів та ін.). Теорії першої групи більше зорієнтовані на удосконалення просторової організації господарства (найбільший досвід їх застосування нагромаджено у Німеччині і колишньому СРСР), другої - на державну допомогу відсталим регіонам (у СРСР, США та ін.), третьої - на 
міжрегіональний перерозподіл економічного зростання (у Франції, Італії та ін.) i четвертої - на збалансоване використання ресурсного потенціалу регіонів (у країнах СС та ін.). Для України, у зв'язку з євроінтеграційними устремліннями, найкориснішим може бути досвід використання теорій четвертої групи. Саме на їх основі слід сформувати ансамбль теорій, на які доцільно спиратися в процесі реформування економіки регіонів.

1. Lösch A. The Economics of Location / A. Lösch. - London : Yale University Press, 1952. - 520 p.

2. Региональная экономика и пространственное развитие. В 2 т. Т. 1. Региональная экономика. Теория, модели и методы [Электронный ресурс] : учебник для бакалавриата и магистратуры / под общ. ред. Л. Э. Лимонова. - М. : Юрайт, 2014. - 397 с. - Режим доступу : http://stud.com.ua/24438/ekonomika/regionalna_ekonomika_teoriya_modeli_i_metodi

3. Гранберг А. Г. Основы региональной экономики : учебник для вузов / А. Г. Гранберг. - [5-е изд, стер. ] - М. : изд. дом ГУ ВШЭ, 2006. -495 с.

4. Кругман П. Пространство: последний рубеж / Пол Кругман // Пространственная экономика. - 2005. - № 3. - C. 121-137.

5. Краткая история Волжского автомобильного завода [Электронный ресурс] // Livejournal. - 2013. 3 сент. - Режим доступа : https://auto-history.livejournal.com/599.html

6. Сонько В. П. Ринок і регіоналістика : навч. посіб. / В. П. Сонько, В. В. Кулішов, В. І. Мустафін. К. : Ніка-Центр, Ельга, 2002. - 380 с.

7. Аральське море [Електронний ресурс]. - Режим доступу : https://ru.wikipedia.org/wiki/\%D0\%90\%D1\%80\%D0\%B0\%D0\%BB $\%$ D1\%8C $\% \mathrm{D} 1 \% 81 \% \mathrm{D} 0 \% \mathrm{BA} \% \mathrm{D} 0$ \%BE\%D0\%B5_\%D0\%BC\%D0\%BE\%D1\%80\%D0\%B5

8. Dennison S. R. The Lokation of Industry and the Depressed Areas / S. R. Dennison. - London : Oxford university press, H. Milford, 1939. $-216 \mathrm{p}$.

9. Что дала США их крупнейшая госкорпорация [Электронный ресурс] // Финмаркет. - 2013. 15 августа. - Режим доступу : http://www.finmarket.ru/economics/article/3438577

10. Эльканов Р.Х. Полюса развития и точки роста инновационной экономики: российский и зарубежный опыт [Электронный ресурс] / Р. Х. Эльканов // Современная наука: актуальные проблемы теории и практики. - 2012. - № 2. - Режим доступу : http://www.vipstd.ru/nauteh/index.php/---ep12-02/388-a

11. Конти С. Приложение теории полюсов роста в региональном развитии (опыт Южной Италии) / С. Конти // Территориально-производственные комплексы: совершенствование процесса формирования / отв. ред. М. К. Бандман. - Новосибирск : Наука. Сиб. отд-ние. 1986. - С. 253-263.

12. Матвіїшин $€$. Зарубіжний досвід надання державної підтримки розвитку потенціалу відсталих $\mathrm{i}$ депресивних територій [Електронний ресурс] / Є. Матвіїшин, О. Нєма // Демократичне врядування. 2009. - $\quad$ Вип. $3 . \quad-\quad$ Режим доступу до журн. : http://www.lvivacademy.com/vidavnitstvo_1/visnik3/fail/+Matvijishyn.pdf

13. Захарченко С. В. Конкурентоспроможність України та іiі регіонів: міжнародний вимір : [монографія] / С. В. Захарченко. - Вінниця : Консоль, 2016. - 413 с.

14. Нуреев Р. М. Экономика развития: модели становления и модернизации рыночной экономики : [учебник] / Р. М. Нуреев. - [2-е изд., перераб. и доп.]. - М. : Норма, 2008. - 367 с.

15. Козьменко С. Ю. Новая экономическая география и обоснование рациональной газотранспортной инфраструктуры региона [Электронный ресурс] / С. Ю. Козьменко, Л. И. Гайнутдинова // Вестник Мурманского государственного технического университета. - 2012. - Т. 15, № 1. - С. 190-194. Режим доступа : http://www.vestnik.mstu.edu.ru/v15_1_n47/articles/190_194_kozmen.pdf

16. Підоричева І. Ю. Теорії регіонального зростання та розвитку 3 інноваційною домінантою / І. Ю. Підоричева // Вісник економічної науки України. - 2014. - № 1. - С. 87-94.

\section{References}

1. Lösch, A. The Economics of Location. London: Yale University Press, 1952.

2. Regional economy. Theory, models and methods. Ed. L.E. Limonov, Yurayt, 2014, stud.com.ua/24438/ekonomika/regionalna_ekonomika_teoriya_modeli_i_metodi. Accessed 1 Dec. 2017.

3. Granberg, A G. Fundamentals of Regional Economics, Ed. house of the Higher School of Economics, 2006.

4. Krugman, P. "Space: The Last Frontier." Spatial Economics, no. 3, 2005, pp.121-137.

5. "A Brief History of the Volzhsky Automobile Plant." Livejournal, 3 Sep. 2013, autohistory.livejournal.com/599.html. Accessed 4 Dec. 2017. 
6. Sonko, V. P., Kulishov, V. V., and V. I. Mustafin. The Market and Regional Studies, Nika-Center, Elga, 2002.

7. "Aral

Sea."

Wikipedia, ru.wikipedia.org/wiki/\%D0\%90\%D1\%80\%D0\%B0\%D0\%BB $\% \mathrm{D} 1 \% 8 \mathrm{C} \% \mathrm{D} 1 \% 81 \% \mathrm{D} 0 \% \mathrm{BA} \% \mathrm{D} 0 \% \mathrm{BE} \%$ D0 \% B5 \% D0\% BC\% D0\% BE\% D1\% 80\% D0\% B5. Accessed 2 Dec. 2017.

8. Dennison, S. R. The Lokation of Industry and the Depressed Areas, Oxford university press, H. Milford, 1939.

9. "What did the US give their largest state corporation." Finmarket, 15 Aug. 2013, www.finmarket.ru/economics/article/3438577. Accessed 4 Dec. 2017.

10. Elkanov, R. Kh. "Poles of development and points of growth of innovative economy: Russian and foreign experience." Modern science: actual problems of theory and practice, no. 2, 2012, www.vipstd.ru/nauteh/index.php/---ep12-02/388-a. Accessed 4 Dec. 2017.

11. Conti, S. "Application of the theory of growth poles in regional development (the experience of Southern Italy)." Territorial production complexes: improving the process of formation, edited by M. K. Bandman, Science. Sib. separation, 1986, pp. 253-263.

12. Matviishin, E., and O. Nemma. "Foreign experience in providing state support to the development of the potential of retarded and depressed territories." Democratic Governance, no. 3, 2009, www.lvivacademy.com/vidavnitstvo_1/visnik3/fail/+Matvijishyn.pdf. Accessed 4 Dec. 2017.

13. Zakharchenko, S. V Competitiveness of Ukraine and its Regions: International Dimension, Console, 2016.

14. Nureev, R. M Development Economics: Model of the Formation and Modernization of the Market Economy, Norma, 2008.

15. Kozmenko, S. Yu., and L. I. Gainutdinova. "New economic geography and rationale of rational gas transport infrastructure of the region." Bulletin of the Murmansk State Technical University, vol. 15, no. 1, 2012, pp. 190-194, www.vestnik.mstu.edu.ru/v15_1_n47/articles/190_194_kozmen.pdf. Accessed 4 Dec. 2017.

16. Podorycheva, I.Yu. "Theories of Regional Growth and Development with Innovative Dominant." Bulletin of Economic Science of Ukraine, no. 1, 2014, pp. 87-94.

\title{
Рецензент:
}

Бондаренко В.М. - доктор економічних наук, професор, декан обліково-фінансового факультету Вінницького торговельно-економічного інституту КНТЕУ.

\section{УДК 336.22 \\ ББК 65.261 \\ ОСОБЛИВОСТІ ОРГАНІЗАЦЇ̈ МІСЦЕВОГО ОПОДАТКУВАННЯ У ЗАРУБІЖНИХ КРАЇНАХ}

\author{
Вінницький навчально-науковий інститут економіки \\ Тернопільського національного економічного \\ університету, \\ Міністерство освіти і науки України, \\ кафедра фінансів, банківської справи та страхування, \\ вул. Гонти, 37, м. Вінниця, \\ 21017, Україна, \\ тел.: (0432) 55-49-55, \\ e-mail: ruslan_vin72@meta.ua
}

Анотація. У статті узагальнено зарубіжний досвід організації місцевого оподаткування та охарактеризовано податкові повноваження органів місцевого самоврядування. Розглянуто практику встановлення та справляння місцевих податків і зборів у Великобританії, Іспанії, Італії, Німеччині, Польщі, Франції та Швеції. В результаті дослідження встановлено, що кожна країна має свої національні особливості в сфері організації місцевого оподаткування. Наукова новизна пов'язана із визначенням характерних ознак і методики запровадження та стягнення 